\title{
PENGARUH LEVERAGE, PROFITABILITAS, DAN UKURAN PERUSAHAAN TERHADAP NILAI PERUSAHAAN MANUFAKTUR SEKTOR INDUSTRI DASAR DAN KIMIA YANG TERDAFTAR DI BEI
}

\author{
Hanseto Suhardi \\ Program Studi Magister Manajemen Universitas Tarumanagara \\ hansetosuhardi@gmail.com
}

Masuk : 30-05-2020, revisi : 24-06-2020 diterima untuk diterbitkan : 24-06-2020

\begin{abstract}
Investor perception of the company as seen from the Firm Value, much factors can affect Firm Value, but the authors only examine three variables, namely Leverage (DAR), Profitability (ROA), and Company Size $=$ Ln (Total assets). This study aims to determine and analyze the effect of Leverage (DAR), Profitability (ROA), and Firm Size on Firm Value of manufacturing companies of the basic and chemical industry. The population in this study is manufacturing companies of the basic and chemical industry which are listed on the Indonesia Stock Exchange for the period of 2016 - 2018. The sampling technique uses purposive sampling, based on the sampling criteria has succeeded in gathering 31 of 76 companies manufacturing basic and chemical sectors. The results showed that the Leverage variable had no effect on Firm Value, the Profitability variable had an effect on Firm Value, and the Firm Size variable had an effect on Firm Value.
\end{abstract}

Abstrak : Persepsi Investor terhadap suatu perusahaan dilihat dari Nilai Perusahaan, Banyak faktor yang bisa mempengaruhi Nilai Perusahaan, tetapi penulis hanya meneliti tiga variabel yaitu Leverage (DAR), Profitabilitas (ROA), dan Ukuran Perusahaan. Penelitian ini bertujuan untuk mengetahui dan menganalisis pengaruh Leverage (DAR), Profitabilitas (ROA), dan Ukuran Perusahaan terhadap Nilai Perusahaan. Populasi dalam penelitian ini adalah perusahaan manufaktur sektor industri dasar dan kimia yang terdaftar di Bursa Efek Indonesia periode 2016 - 2018. Teknik pengambilan sampel menggunakan purposive sampling, berdasarkan kriteria sampling telah berhasil mngumpulkan 31 dari 76 perusahaan manufaktur sektor dasar dan kimia. Hasil penelitian menunjukkan bahwa variabel Leverage tidak berpengaruh terhadap Nilai Perusahaan, variabel Profitabilitas berpengaruh terhadap Nilai Perusahaan, dan variabel Ukuran Perusahaan berpengaruh terhadap Nilai Perusahaan.

Keywords : Firm Value, Leverage, Profitability, Company Size

\section{PENDAHULUAN}

Harga saham merupakan salah satu penilaian dari nilai perusahaan. Jika harga saham meningkat, maka nilai perusahaan juga akan ikut meningkat, sehingga berdampak pada peningkatan nilai pemegang saham yang dibuktikan melalui tingginya return bagi pemegang saham. Keadaan inilah yang mencerminkan kemakmuran para pemegang saham perusahaan (Novari \& Lestari, 2016). Sehingga dalam hal ini ukuran keberhasilan manajemen perusahaan dilihat dari kemampuan perusahaan menyejahterahkan para pemegang saham. (Suwardika \& Mustanda, 2017) menunjukkan bahwa Leverage berpengaruh secara positif terhadap Nilai Perusahaan. Nilai Perusahaan dipengaruhi oleh besar kecilnya Leverage yang dihasilkan oleh perusahaan. Jika Leverage semakin besar, maka menunjukkan risiko investasi yang semakin besar pula dan ini akan mempengaruhi Nilai Perusahaan. (Chen \& Chen, 2011) menunjukkan bahwa Profitabilitas berpengaruh secara positif terhadap Nilai Perusahaan. Profitabilitas menunjukkan kemampuan perusahaan memperoleh laba atau ukuran efektivitas pengelolaan manajemen. (Siahaan, 2013) menunjukkan secara signifikan terdapat pengaruh positif antara 
Ukuran Perusahaan terhadap Nilai Perusahaan, artinya peningkatan Ukuran Perusahaan akan mempermudah perusahaan memperoleh pendanaan, yang kemudian dimanfaatkan oleh pihak manajemen untuk meningkatkan Nilai Perusahaan. Penelitian ini dilakukan pada perusahaan manufaktur sektor industri dasar dan kimia yang terdaftar di Bursa Efek Indonesia dengan alasan perkembangan perusahaan manufaktur sektor industri dasar dan kimia di Indonesia berkembang cukup pesat. Hal ini dibuktikan karena adanya peningkatan saham-saham perusahaan manufaktur di sektor tersebut

\section{TINJAUAN PUSTAKA}

\section{Nilai Perusahaan}

Nilai perusahaan merupakan nilai pasar perusahaan atas surat berharga hutang dan ekuitas perusahaan yang beredar. Memaksimalkan nilai perusahaan sangat penting artinya bagi suatu perusahaan, karena dengan memaksimalkan nilai perusahaan berarti juga memaksimalkan kemakmuran pemegang saham yang merupakan tujuan utama perusahaan (Sakdiah, 2019). Dalam penelitian yang dilakukan oleh (Fernandes , 2013) dijelaskan bahwa nilai nilai perusahaan merupakan gambaran investor terhadap perusahaan yang dihubungkan dengan harga saham, sehingga harga saham menjadi alat ukur bagi para investor dalam menentukan nilai dari suatu perusahaan serta pengaruhnya bagi keputusan berinvestasi para investor dalam suatu perusahaan. Semua perusahaan pasti ingin memperoleh keuntungan semaksimal mungkin dan memaksimalkan nilai perusahaan. (Siahaan, 2013)

\section{Leverage}

Leverage adalah penggunaan aktiva atau dana dimana untuk menggunakannya perusahaan harus membayar biaya tetap (Bambang, 2008). financial leverage didefinisikan sebagai tingkat penggunaan hutang sebagai sumber pembiayaan perusahaan (Weston \& Brigham, 1998). Dari beberapa pengertian menurut para ahli dapat disimpulkan bahwa leverage merupakan penggunaan hutang oleh perusahaan sebagai sumber pembiayaan untuk melakukan kegiatan perusahaan dimana untuk menggunakannya perusahaan harus membayar biaya tetap. Rasio leverage dalam penelitian ini diproksikan dengan rasio Debt to Assets Ratio (DAR). Menurut hasil penelitian terdahulu yang dilakukan oleh (Chen \& Chen, 2011) menghasilkan penelitian bahwa Leverage berpengaruh negatif terhadap Nilai Perusahaan.

\section{Profitabilitas}

Profitabilitas adalah rasio untuk menilai kemampuan perusahaan dalam mencari keuntungan. Profitabilitas ini memberikan gambaran seberapa efektif perusahaan beroperasi sehingga memberikan laba bagi perusahaan (Kasmir, 2014). Penggunaan rasio profitabilitas dapat dilakukan dengan menggunakan perbandingan antara berbagai komponen yang ada di laporan keuangan, Tujuannya adalah agar terlihat perkembangan perusahaan dalam rentang waktu tertentu, baik penurunan atau kenaikan, sekaligus mencari penyebab perubahan tersebut (Kasmir, 2014). Rasio yang digunakan untuk mengukur profitabilitas dalam penelitian ini adalah Return on Asset (ROA). Menurut hasil penelitian terdahulu yang dilakukan oleh (Komarudin \& Affandi, 2019) menghasilkan penelitian bahwa Profitabilitas berpengaruh signifikan terhadap Nilai Perusahaan.

\section{Ukuran Perusahaan}

Ukuran Perusahaan adalah salah satu variabel yang dipertimbangkan dalam menentukan nilai suatu perusahaan. Ukuran perusahaan merupakan cerminan total dari aset yang dimiliki suatu perusahan (Pratama \& I Gusti Bagus, 2016). Secara umum, ukuran perusahaan diukur dengan besarnya total aset yang dimiliki karena nilai total asset umumnya sangat besar dibandingkan variabel keuangan lainnya (Rahmawati, Topowijono, \& Sri, 2015). Rasio yang digunakan untuk mengukur Ukuran Perusahaan adalah Price to Book Value (PBV). Menurut hasil penelitian terdahulu yang dilakukan oleh (Zuhroh, 2019) menghasilkan penelitian bahwa Ukuran Perusahaan berpengaruh terhadap Nilai Perusahaan 


\section{METODE PENELITIAN}

Penelitian ini merupakan jenis penelitian penjelasan (explanatory research), yaitu penelitian yang bertujuan untuk menjelaskan hubungan- hubungan antara satu variabel dengan variabel lainnya melalui pengujian hipotesis. Penelitian ini dilakukan di Indonesia dengan menganalisis perusahaan-perusahaan Manufaktur yang terdaftar di Bursa Efek Indonesia (BEI) sektor industri dasar dan kimia tahun 2016-2018. Populasi yang digunakan dalam penelitian ini adalah seluruh perusahaan manufaktur sektor industri dasar dan kimia yang terdaftar di Bursa Efek Indonesia (BEI) pada tahun 2016 sampai dengan tahun 2018. Bedasarkan data yang diperoleh dari Bursa Efek Indonesia (BEI), terdapat 76 perusahaan manufaktur sektor industri dasar dan kimia yang terdaftar pada tahun 2016 sampai dengan tahun 2018. Dari 76 perusahaan perusahaan tersebut, terdapat 31 sampel perusahaan yang memenuhi kriteria sampel penelitian yang telah ditetapkan. Dalam penelitian ini, peneliti menggunakan variabel independen dan variabel dependen.

\section{Variabel Dependen}

Nilai Perusahaan

PBV (Price Book Value) adalah rasio antara harga perlembar saham dengan nilai buku perlembar saham pada suatu perusahaan. Variabel nilai perusahaan diberikan symbol FV. Rasio ini digunakan untuk menilai suatu ekuitas berdasarkan nilai bukunya (Siahaan, 2013) :

\section{Variabel Independen}

$$
\mathrm{FV}=\frac{\text { Harga Saham }}{\text { Nilai buku per lembar saham }}
$$

\section{Leverage}

Rasio DAR merupakan rasio utang yang digunakan untuk mengukur seberapa besar aktiva perusahaan dibiayai oleh utang atau seberapa besar utang perusahaan berpengaruh terhadap pengelolaan Aktiva (Kasmir, 2014). Perhitungan DAR dilakukan dengan menggunakan rumus:

Profitabilitas

$$
D A R=\frac{\text { total hutang }}{\text { total asset }}
$$

Rasio profitabilitas merupakan rasio yang digunakan untuk menilai kemampuan perusahaan dalam mencari keuntungan atau laba dalam suatu periode tertentu (Farah, 2014). Dalam penelitian ini peneliti menggunakan rasio ROA dengan rumus:

Ukuran Perusahaan

$$
\mathrm{ROA}=\frac{\text { Net } \text { Profit After } \text { Tax }}{\text { Total Asset }} \text {. }
$$

Ukuran Perusahaan mengacu pada nilai logaritma natural dari total aset (natural logarithm of asset) (Said, Asnawi, \& Chandra, 2005). Rumus Ukuran Perusahaan sebagai berikut:

\section{Metode Analisis Data}

$$
\text { Size }=\operatorname{Ln}(\text { Total asset })
$$

Pengujian hipotesis ini digunakan untuk mengetahui apakah terdapat pengaruh antara Leverage, Profitabilitas, dan Ukuran Perusahaan terhadap Nilai Perusahaan. Model analisis data yang digunakan dalam penelitian ini adalah analisis linear berganda. Model persamaan regresi linear yang digunakan dalam penelitian ini adalah sebagai berikut:

$$
Y=\alpha+b 1 \times 1+b 2 \times 2+b 3 \times 3+e
$$

Keterangan :

$\mathrm{Y}=$ Nilai Perusahaan $; \alpha=$ Nilai Konstanta; $\mathrm{b} 1-\mathrm{b} 3=$ Koefisien Regresi; $\mathrm{X}_{1}=$ Leverage $\mathrm{X}_{2}=$ Profitabilitas; $\mathrm{X}_{3}=$ Ukuran Perusahaan; e = Variabel Pengganggu 


\section{HASIL DAN PEMBAHASAN \\ Uji-t (Uji Parsial)}

Uji ini digunakan untuk menguji pengaruh masing-masing variabel bebasnya secara sendiri-sendiri terhadap variabel terikatnya.

\section{Uji pengaruh Leverage terhadap Nilai Perusahaan}

Dari hasil uji t diperoleh nilai signifikan probabilitas untuk variabel Leverage sebesar 0.8579 , lebih besar dari $\alpha=0.05$, maka Ho diterima artinya tidak terdapat pengaruh Leverage terhadap Nilai Perusahaan.

\section{Uji Pengaruh Profitabilitas terhadap Nilai Perusahaan}

Dari hasil uji t diperoleh nilai signifikan probabilitas untuk variabel Profitabilitas sebesar 0.0176 , lebih kecil dari $\alpha=0.05$, maka Ha diterima artinya terdapat pengaruh Probabilitas terhadap Nilai Perusahaan.

\section{Uji Pengaruh Ukuran Perusahaan terhadap Nilai Perusahaan}

Dari hasil uji t diperoleh nilai signifikan probabilitas untuk variabel Ukuran Perusahaan sebesar 0.0488 , lebih kecil dari $\alpha=0.05$, maka Ha diterima asrtinya terdapat pengaruh Ukuran Perusahaan terhadap Nilai Perusahaan.

\section{KESIMPULAN}

Berdasarkan hasil analisis data yang telah dilakukan, maka dapat diambil kesimpulan sebagai berikut:

1. Tidak terdapat pengaruh Leverage terhadap Nilai Perusahaan

2. Terdapat pengaruh Profitabilitas terhadap Nilai Perusahaan

3. Terdapat pengaruh Ukuran Perusahaan terhadap Nilai Perusahaan

4. Terdapat pengaruh Leverage, Profitabilitas dan Ukuran Perusahaan secara bersama sama terhadap Nilai Perusahaan.

\section{DAFTAR PUSTAKA}

B. R. (2008). Dasar-Dasar Pembelajaan Perusahaan. Yogyakarta : BPFE.

Chen, L. J., \& Chen, S. Y. (2011). The Influence of Profitablity on Firm Value with Capital Structqure as The Mediator and Firm Size and Industry as Moderators. Investment Management and Financial Innovations, 120-129.

F. M. (2013). Struktur Modal, Profitabilitas, dan Struktur Biaya terhadap Nilai Perusahaan Industri Keramik, Porcelen dan Kaca Periode 2007-2011. Jurnal EMBA, 433-442.

F. M. (2014). Dasar-dasar Manajemen Keuangan. Jakarta : Dian Rakyat.

Kasmir. (2014). Analisis Laporan Keuangan. Jakarta : Rajawali Pers.

Komarudin, M., \& Affandi, N. (2019). Firm Value, Capital Structure, Profitability, Fiem Characteristic and Disposable Income as Moderator: an Empirical Investigation of Retail Firms in Indonesia. INOVBIZ : Jurnal Inovasi Bisnis, 79-85.

M. R., \& B. S. (2018). Faktor-faktor yang Mempengaruhi Nilai Perusahaaan. IKRAITHHUMANIORA, 69-76.

Novari, P. M., \& Lestari, P. V. (2016). Pengaruh Ukuran Perusahaan, Leverage, dan Profitabilitas terhadap Nilai Perusahaan pada Sektor Properti dan Real Estate. E-Jurnal Manajemen Unud, 5671-5694.

Pratama, I. A., \& I. W. (2016). Pengaruh Ukuran Perusahaan dan Leverage terhadap Nilai Perusahaan dengan Profitabilitas sebagai Variabel Mediasi. E-Jurnal Manajemen Unud, 1338-1367.

Rahmawati, A. D., Topowijono, \& S. S. (2015). Pengaruh Ukuran Perusahaan, Profitabilitas, Struktur Modal dan Keputusan Investasi terhadap Nilai Perusahaan. Jurnal Administrasi Bisni (JAB), 1-7.

S. K., Asnawi, \& C. W. (2005). Riset Keuangan Pengujian-pengujian Empiris. Jakarta : Gramedia Pustaka. 
Sakdiah. (2019). Pengaruh Profitabilitas, Leverage, Ukuran Perusahaan dan Likuiditas Terhadap Kebijakan Dividen dan Nilai Perusahaan. Jurnal Jurusan Tadris IPS Society, 133-153.

Siahaan, F. O. (2013). The Effect of Good Corporate Governance Mechanism, Laverage, and Firm Size on Firm Value. GSTF Journal on Business Review, 137-142.

Suwardika, I. A., \& Mustanda, I. K. (2017). Pengaruh Leverage, Ukuran Perusahaaan, Pertumbuhan Perusahaan, dan Profitabilitas terhadap Nilai Perusahaan pada perusahaan properti. E-Jurnal Manajemen Unud, 1248-1277.

Ummi, K., Kalbuana, N., \& Mulyati, H. (2016). Pengaruh Leverage, Profitabilitas, dan Ukuran Perusahaan terhadap Nilai Perusahaan. Syariah Paper Accounting, 71-81.

Wahyudi, H. D., Chuzaimah, \& D. S. (2016). Pengaruh Ukuran Perusahaan, Profitabilitas, Kebijakan Deviden, dan Keputusan Investasi terhadap Nilai Perusahaan. BENEFEIT Jurnal Manajemen dan Bisnis, 156-164.

Weston, J. F., \& Brigham, F. E. (1998). Manajemen Keuangan. Jakarta : Erlangga.

Zuhroh, I. (2019). The Effects of Liquidity, Firm Sizee, and Profitability on the Firm Value eith Mediating Leverage. 2nd International Conference on Islamic Economics, Business, and Philanthropy (ICIEBP), 203-230. 